УДК 629.12.001.57

DOI 10.47049/2226-1893-2020-2-72-89

\title{
THEORETICAL AND EXPERIMENTAL INVESTIGATIONS OF WAVE FIELD AROUND VESSEL IN SHALLOW WATER
}

\author{
N. Efremova \\ P.h.D., Associate Professor Department \\ «Ship theory and design department named after prof. Y.L. Vorobyov» \\ Odessa National Maritime University, Ukraine, Odessa \\ A. Nilva \\ P.h.D., Chief Scientific researcher \\ Marime Engineering Bureau, Ukraine, Odessa \\ N. Kotovskaya, M. Driga \\ senior lecturers of the department \\ «Ship theory and design department named after prof. Y.L. Vorobyov» \\ Odessa National Maritime University, Ukraine, Odessa
}

Abstract. Un-running vessel at the shallow-water road anchorage is under exposure to waves that come at arbitrary angle from the high sea. $3 D$ waves from deep-sea area become practically $2 D$ when entering shallow water. While mean periods are kept, waves become shorter and their crests become higher and sharpener than for deep-water ones.

As a result of diffraction of waves that come from the deep-water sea at the vessel, a transformation zone appears where waves become $3 D$ again. Dimensions of the waves' transformation zone, character and height of waves in this zone specify safety of auxiliary crafts, e.g. tugboats, bunker vessels, pilot and road crafts, oil garbage collectors and boom crafts. In the complex $3 D$ waves the trajectory of auxiliary vessel's movement has to be safe, vessel's motions have to be moderate. Besides waves' height is one of the parameters that are used for forecast of movement of spilled oil.

Last years the biggest part examination of waves' problems was devoted to estimation of waves' impact onto stationary or floating shelf facilities. For validity estimation, waves' characteristics defined due to different theories, are compared with experimental ones. But characteristics of the waves around shelf facilities are hardly able to be compared to same ones of waves around bodies with vessel-type shape.

At the experiments with vessels' models, waves' impact onto vessel was examined, but not the transformation of the waves themselves. So, comparing of waves area's characteristics defined by both theoretical experimental ways is an actual problem.

(C) Efremova N., Nilva A., Kotovskaya N., Driga M., 2020 
Aim of the paper is verification of results of wave area investigation; wave area is located around a vessel that is exposed of arbitrary angle waves at shallow water conditions.

Description of experimental investigations of transformed waves in the towing tank is done; transformation zone appears around vessel's model while running waves diffract on it. Distribution of waves' amplitudes at the designated points was fixed by the special designed and manufactured unit. Experimental data is compared with computation results both of linear and non-linear theories. It was assumed that experimental results and theoretical data satisfactory meet each other; also that non-linear computations define the maximal values of waves' amplitudes at all cases.

Keywords: waves' diffraction at a vessel, waves' amplitude, significant shallow water, towing tanks, experiment.

УДК 629.12.001.57

DOI 10.47049/2226-1893-2020-2-72-89

\title{
ТЕОРЕТИКО-ЕКСПЕРИМЕНТАЛЬНІ ДОСЛІДЖЕННЯ ХВИЛЬОВОГО ПОЛЯ ПОБЛИЗУ СУДНА НА МІЛКОВОДДІ
}

\author{
Н.В. Єфремова \\ кандидат технічних наук, \\ доцент кафедри «Теорія і проектування корабля ім. проф. Ю.Л. Воробйова» \\ Одеський начіональний морський університет, Украӥна, м. Одеса
}

А.Є. Нильва

кандидат технічних наук, провідний науковий співробітник

Морське Інженерне бюро, Украӥна, м. Одеса

Н.Н. Котовська, М.В. Дрига

ст.викладачі кафедри

«Теорія і проектування корабля ім. проф. Ю.Л. Воробйова»

Одеський національний морський університет, Украӥна, м. Одеса

Анотація. Судно, щзо плаває без ходу на мілководній рейдовій стояниі, є під впливом хвилювання, що набігає під довільним кутом з боку відкритого моря. Хвилювання, щзо набігає, та дифраговане хвилювання створюють навколо судна зону трансформачії, де хвилювання стає тривимірним. Розміри иієї зони, характер і висота хвиль у ній визначають безпечну експлуатацію допоміжних суден - буксирів, бункерувальників та ін.

Протягом останніх років більшість рішень хвильових задач присвячені оціниі впливу хвиль на шельфові спорудження. Для оцінки вірогідності характеристики хвилювання, розраховані за різними теоріями, 
ВІСНИК

ОДЕСЬКОГО НАЦІОНАЛЬНОГО

МОРСЬКОГО УНІВЕРСИТЕТУ № 2 (62), 2020
HERALD

OF THE ODESSA NATIONAL

MARITIME UNIVERSITY № 2 (62), 2020

порівнюються з експериментами. Однак характеристики хвиль навколо шельфових споруджень складно зіставити із хвилюванням навколо тіл судноподібної форми. В експериментах з моделями суден вивчається вплив хвиль на судно, але трансформаџія самого хвилювання навколо судна не досліджується. Тому порівняння характеристик хвильового поля, визначених розрахунковим і експериментальним иляхом, $\epsilon$ актуальною задачею.

У наведеній статті описане експериментальне дослідження у дослідному басейні амплітуд трансформованих хвиль, щуо виникають навколо моделі судна при дифракиії на неї хвилювання, щуо набігає. Розподіл амплітуд хвилювання в заданих точках визначалося за допомогою спеціально спроектованого та виготовленого для иієї мети устаткування. Виконане порівняння експериментальних даних з результатами розрахунків за лінійною і нелінійною теоріями. Зроблені висновки про задовільний збіг результатів експериментів з теоретичними даними, а також про те, щчо розрахунки за нелінійною теорією у всіх випадках визначають максимальні значення хвильових амплітуд.

Ключові слова: дифракиія хвиль на судні, амплітуда хвилювання, значне мілководдя, дослідний басейн, експеримент.

\section{УДК 629.12.001.57}

DOI 10.47049/2226-1893-2020-2-72-89

\section{ТЕОРЕТИКО-ЭКСПЕРИМЕНТАЛЬНЫЕ ИССЛЕДОВАНИЯ ВОЛНОВОГО ПОЛЯ ВБЛИЗИ СУДНА НА МЕЛКОВОДЬЕ}

\section{Н.В. Ефремова}

кандидат технических наук, доцент кафедры «Теория и проектирование корабля им. проф. Ю.Л. Воробьева»

Одесский наџиональный морской университет, Украина, Одесса

\section{А.Е. Нильва}

кандидат технических наук, ведущий научный сотрудник

Морское Инженерное бюро, Украина, г. Одесса

Н.Н. Котовская, М.В. Дрыга

ст. преподаватели кафедры

«Теория и проектирование корабля им. проф. Ю.Л. Воробьева»

Одесский национальный морской университет, Украина, г. Одесса

Аннотация. Судно, плавающее без хода на мелководной рейдовой стоянке, находится под воздействием волнения, набегающего под произвольным углом со стороны открытого моря. Набегающее и дифрагированное волнение создают вокруг судна зону трансформации, где волнение становится трехмерныл. Размеры этой зоны, характер и высота волн в ней определяют безопасность эксплуатации вспомогательных судов. 
В последние годы большинство решений волновых задач посвящены оченке влияния волн на шельфовые сооружения. Для оценки достоверности характеристики волнения, рассчитанные по различным теориям, сравниваются с экспериментами. Однако характеристики волн вокруг шельфовых сооружений сложно сопоставить с волнением вокруг тел судоподобной формы. В экспериментах с моделями судов изучается воздействие волн на судно, но трансформация самого волнения вокруг судна не исследуется. Поэтому сравнение характеристик волнового поля, определенных расчетным и экспериментальным путем, является актуальной задачей.

В представленной работе описано экспериментальное исследование в опытовом бассейне амплитуд трансформированных волн, возникающих вокруг модели судна при дифракции на ней набегающего волнения. Распределение амплитуд волнения в заданных точках определялось $c$ помощью специально спроектированной и изготовленной для этой иели установки. Выполнено сравнение экспериментальных данных с результатами расчетов по линейной и нелинейной теориям. Сделаны выводы об удовлетворительном совпадении результатов экспериментов с теоретическими данными, а также о том, что расчеты по нелинейной теории во всех случаях определяют максимальные значения волновых амплитуд.

Ключевые слова: дифракиия волн на судне, амплитуда волнения, значительное мелководье, опытовый бассейн, эксперимент.

Statement of a problem. As it is shown by the analysis of papers of all over the world researchers, last some decades a transition from linear theories and methods to non-linear ones is observes for solving marine hydrodynamics problems. It is expedient for breaking zone of inshore waves, for long waves at shallow water, and also for abrupt wind waves in conditions of deep-water area.

The part of the Black Sea adjoined to Ukraine is characterized by complex wind-wave conditions, especially in the winter. This water area is rather shallow. Abrupt wind waves and also long ripple waves are observed in the coastal zone in the area of ports location.

Waves came from high sea to the ports area transform at shallow water. Three-dimensional deep-water waves become practically bi-dimensional due to influence of local weather and bottom relief. Long waves become shorter, small waves become longer and higher [1].

This paper is devoted to the analysis of a specific situation which arises at port's road anchorage, where large vessels are loaded in addition or partly unloaded or are bunkered in the conditions of waves came from high sea. Thus vessels themselves are an obstacle for running waves. In such way the secondary transformation zone is appeared around the vessel as a result of superposition of came and diffracted waves. 
A lot of auxiliary boats work near large vessels at open port road anchorage, namely: tugboats, bunker vessels, pilot and road crafts, oil garbage collectors and boom crafts. In the complex three-dimensional waves the trajectory of auxiliary vessel's movement has to be safe, vessel's motions have to be moderate. Also it has been taken into account waves' height is one of the parameters that are used for forecast of movement of spilled oil [2].

For these problems solving it is necessary to define characteristics of a wave field, namely waves' length and height at the wave transformation zone near to large vessel at port road anchorage.

The review of last achievements and literatures. Last years the biggest part examination of waves' problems was devoted to estimation of waves' impact onto stationary or floating shelf facilities. In paper [3] the review of the basic equations which allow to define waves transformation at inshore zone is given; applicability scopes for various theories are specified; waves' diffraction on underwater breakwaters and in harbours with a flat bottom is studied.

$\mathrm{Bi}$ - and three-dimensional numerical modelling of uprush of nonlinear surface gravity waves at shallow water on the basis of Stokes equations is described in the paper [4]. Results of investigations for slopes of various bottom geometry are analysed. Models of stage-by-stage uprush of nonlinear surface gravity waves onto shore-protection constructions are considered.

In the paper [5] it is given the solution of the diffraction problem of ocean waves against a hollow vertical cylinder at the finite depth. The problem was studied for Oscillating Water Column (OWC) that utilizes the energy of ocean waves in order to generate electricity. The wave field created by the oscillating vertical cylinder is defined in the paper [6].

Wave fields and wave loads that appeared at the vertical movement of the vertical circular cylinders are defined by the finite elements method in the paper [7]. The first and second order potential problems are solved for the single cylinder and groups of two and four cylinders.

Numerical modelling of influence of nonlinear waves onto system of two vertical circular cylinders (one is rigidly fixed at the bottom and another floats) is described in the paper [8]. Wave forces and the moments are resulted together with movements of the floating cylinder.

It is necessary to point also numerical (CFD) modelling of interactions of waves with the vertical cylinder resulted in paper [9]. Regular and irregular waves of small and finite amplitudes (second-order Stokes) were modeled in the numerical towing tank; characteristics of waves and wave forces were obtained. Reliability of waves' characteristics defined due to different theories is estimated by comparison with results of experimental researches.

Results of definition of hydrodynamic forces coefficients and free surface height for case of nonlinear waves impact onto on the vertical single cylinder or group of four cylinders are given in the paper [10]. 
Computations are made by the Final Differences Method (FDM) and the Final Elements Method (Weakly Nonlinear and Weakly Dispersive FEM, Fully Nonlinear and Weakly Dispersive FEM); results are compared to experimental data.

Paper [11] contains the full analytical solution of the second order diffraction problems for motionless rectangular cylinders on the free surface of finite depth liquid. Reliability of definition of vertical and horizontal forces of the first and second orders is confirmed by comparison to experiments and computations of other authors.

The experimental investigation of waves impact onto the floating cylinder moored to the berth is resulted in the paper [12]. Ocean waves are modelled in a small-sized wave flume. Results of research contain waves' characteristics and cylinder movements.

Reflection and transmission of a floating dock with nonlinear water waves) at shallow water is described in the paper [13]. Theoretical solutions, namely analytical and by the method of matched eigen-function expansions were confirmed by the experimental way. Results of investigations contain amplitudes of the nonlinear reflected and transmitted waves for several combinations of the dock sizes and water depth.

Characteristics of waves around the described above objects can be hardly compared to same ones of waves around bodies with vessel-type shape. Firstly, rectangular and circular sections of cylinders differ from vessel's frame sections. Secondly, rather smooth forms of vessel's end essentially differ from sharp ends of the horizontal floating cylinders. Thirdly, the flow around of the elongated vessel essentially differs from the flow around the groups of vertical cylinders located in a line.

Diffraction problem for vessels is solved rather seldom. On the one hand, it's explained by nonlinearity of the area occupied by a liquid and nonlinearity of the free surface boundary condition. When investigating vessel's motions, on the other hand, diffraction forces can be defined from the solving of more simple radiation problem [14]. The solution of the diffraction problem in concrete cases requires adjustment and specialization of boundary conditions.

Radiation potential and diffraction potential for longitudinal motions of the vessel running in significant shallow water are defined in the paper [15] by matched asymptotic expansion method (MAEM). Radiation potentials of for surging, heaving and pitching motions are resulted, such as expressions for components of diffraction potential for heaving.

The numerical solution of three-dimensional potential problem for vessel's motions in the finite depth liquid is given in the paper [16]. Influence of depth change for added masses and damping coefficients for different types of vessels is investigated. 
The bi-dimensional nonlinear potential problem concerning frame contour motions in the finite depth liquid is solved in the paper [17] in view of nonlinearity of boundary conditions at free surface of liquid and at frame's contour. Nonlinear forces for different depths and for different forms of frames are defined by second order accuracy. investigations.

Unfortunately, the papers [15-17] don't contain results of experimental

In the paper [18] it is described theoretical (CFD) and experimental (towing tank) modelling of vessel-waves interaction, resulting evaluation of such effects as slamming, green water, air-gap exceedance.

Modelling of green water effects for osculating non-self-propelled marine barge of rectangular pontoon form are resulted in [19]. Experimental investigations are carried out for deep water and regular waves. Waves' steepness is $h / \lambda=1 / 21,2-1 / 26,5$; it corresponds to the high sea. The given waves' characteristics are close to greatest possible for towing tank of ONMU due to waves' heights and wave-damping effectiveness. Parameters of waves correspond to characteristics of irregular $3 \%$ probability waves of the operational area.

Waves' impact onto a vessel is investigated in the papers [18-19], however waves' transformation around the vessel is not investigated.

Thus, there are no reliable practical recommendations for estimation of parameters of a wave field around a vessel at open port road anchorage. Comparison of the wave field characteristics defined by analytical and experimental ways is an actual problem.

Aim of investigations, statement of a problem. Aim of the paper is verification of results of wave area investigation; wave area is located around a vessel that is exposed of arbitrary angle waves at conditions of shallow water port road anchorage. For this purpose it is necessary to compare results of computations of waves' characteristics around a vessel made by linear and nonlinear theories, to corresponding experimental data.

The basic material of investigation. Results of definition of the transformed waves' characteristics at the set points near to the motionless elongated vessel at shallow water are presented in papers [20] and [21]. Linear diffraction problem solving is resulted in the paper [20], nonlinear diffraction problem solving (fifth order Stokes method) is resulted in the paper [20]. In both cases waves run against vessel at arbitrary angle. Linear and nonlinear waves' profile results for the incoming side are shown in the paper [21]. A set of parameters is varied: waves' steepness, water depth, waves' course angle. Similarity and differences of waves' profiles are described.

The experimental investigation of amplitudes of wave field arising around a vessel's model during diffraction of running waves on the model was carried out in 1998-2000 in towing tank named in honour of A.A. Kostyukov (OSMU). 
Some preliminary results are shown in the paper [22], the detailed description experiments' results is given in the paper [23].

Object of research was the wave field created by plate wavemaker in the towing tank both for deep water and shallow water with and without vessel's model in the towing tank. Parameters of regular waves (length and height) were set in accordance to model's dimensions and depth of water of the towing tank.

The towing tank represents a ferroconcrete bath of $36 \mathrm{~m}$ length, $6 \mathrm{~m}$ width and 2,25 $\mathrm{m}$ depth. The towing tank has parabolic cross-section section, therefore shallow water was simulated by help of mounting of additional wooden bottom.

Experimental investigations were carried out for model of the «Zoya Kosmodemyanskaya» bulk carrier (scale 1:100) with main dimensions (model): $L=2,016 \mathrm{~m}, B=0,318 \mathrm{~m}, T=0,117 \mathrm{~m}$.

Distribution of waves' amplitudes around the model at the designated points (by towing tank's length and width) was fixed by the special designed and manufactured unit. The scheme of experimental unit is given in the Figure. 1.

The vessel's model (1) loaded by CWL is fastened motionlessly to turn frame (8) under the set angle to the running waves. The turn frame is located on a rail way (4). The mobile carriage (2) with the measuring equipment (3) and the wave sensor (6) are located on the same rail way. Two more wave sensors (5) and (7) are located along the towing tank on its axis; sensor (7) is constantly fixed before the model at the distance of $l=6000 \mathrm{~mm}$ from the turn frame' (8) axis and measures parameters of the unperturbed waves (far before model). Wave sensors (5) and (6) are located at designated distances of towing tank's axis and the model's middle; they measure wave parameters near the model both at incoming side and at the zone of hydrodynamic shadow.

Water depth $H$ above the additional bottom (10) was set by pumping/discharging waters at the towing tank.

The wave period is set by choice of frequency of wavemaker plate's (9) oscillation; wave height is set by choice of corresponding radius of a crank of the wavemaker's drive.

Wave sensors of the of string type were connected to the input of tenso-amplifier located on the mobile carriage (2). Further signals (proportional to wave's amplitudes) from the tenso-amplifier are forwarded to the registrator (light-ray oscillograph) through the cable. Measurements of wave amplitudes are made at that point of the record where wave processes become stable. Sample of oscillogram is shown in the Figure 2.

Defined values of wave amplitudes turn out as product of the sizes measured at oscillograms and corresponding scale factors. 


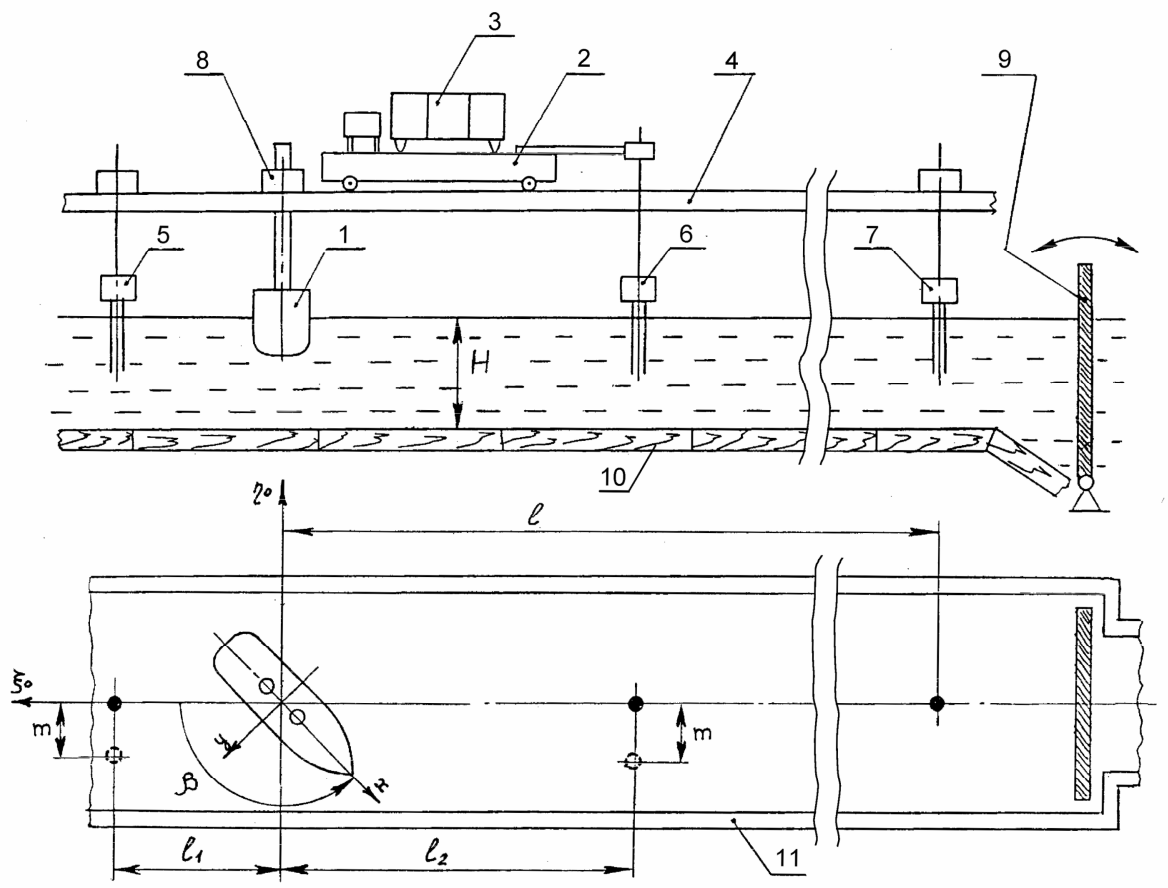

Figure 1. Experimental unit scheme:

1 -vessel's model; 2 - mobile carriage; 3 - measuring equipment;

4 -rail way; 5,6,7-wave sensors; 8 -turn frame;

9 -wavemaker's plate; 10 -additional bottom; 11 -towing tank's wall

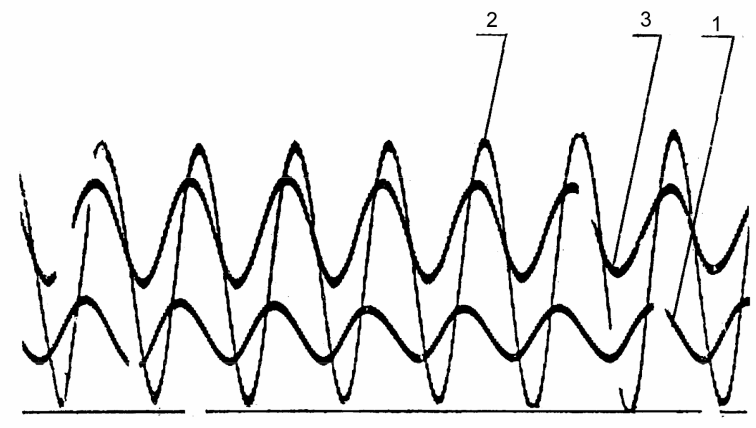

WWWWWWWWWWWWWWWWWWWWWWW

4

Figure 2. Sample of oscillogram:

1 - record of wave, sensor behind model;

2 - record of wave, sensor before model;

3 - record of wave, sensor at far distance before model; 4 - record of time 
Measurements were carried out for three course angles of running waves $\beta=90^{\circ} ; 135^{\circ} ; 180^{\circ}$. Wave parameters are as follows: relative lengths $\lambda / L=0,25 ; 0,5 ; 1,0$, relative heights $h / \lambda$ is within the range $1 / 40-1 / 100$. It is necessary to note, that during the specified period of time more abrupt waves were not modelled in the towing tanks.

At the shallow water tests relative depth was $H / T=1,1 ; 1,3 ; 2,0$. It is necessary to note, that in this towing tank test at relative depth $H / T=1,1$ was made for the first time. It became possible as the model of a vessel was motionless. The minimal value of relative depth at earlier tests for moving models was $H / T=1,3$. Results of measurements of deep water waves further have not been used.

Location of the wave sensors (Figure 1):

- for course angles $90^{\circ}$ and $135^{\circ}$ - three ones: (7) at far distance from model at the towing tank's axis, (5) and (6) - at three positions by model's length $(2 m / L=0,2 m / L=0,5,2 m / L=1,0)$. Distances from the model's sides to sensors was:

- for course angle $90^{\circ} \quad l_{1}=l_{2}=200,300, \ldots, 1800 \mathrm{~mm}$ for all three positions;

- for a course corner $135^{\circ} l_{1}=100,200, \ldots, 1600 \mathrm{~mm}$ for all three positions, $l_{2}=700,800, \ldots, 2100 \mathrm{~mm}$ for $2 \mathrm{~m} / L=0$, for two other positions $l_{2}=800,900, \ldots, 2200 \mathrm{~mm}$;

- for course angle $180^{\circ}$ - two ones: (7) at far distance from model at the towing tank's axis, (5) at two positions by towing tank's width at distances $B$ and $2 B$ from model's sides. Distances from model's middle to the sensor (5) was $l_{1}=520,320,120 \mathrm{~mm}, l_{2}=80,280,480,680 \mathrm{~mm}$.

Results of researches. Results of experiments are values of relative wave amplitudes $\bar{\varsigma}=\varsigma / a$ ( $a-$ the amplitude of running waves, it is defined by sensor (7), see Figure 1). Lines of sensor's arrangement in all experiences are parallel to the towing tanks axis, therefore computation results of relative wave amplitudes $\bar{\varsigma}=\bar{\varsigma}\left(\bar{\xi}_{0}\right), \bar{\xi}_{0}=2 \xi_{0} / L$ for all course angles is made along the same towing tanks' axis (at the beginning all computations were carried out in the vessel's coordinate system, see Figure 1).

As an example, experimental points and computational curves are plotted in the Figures 3-5 for designated water depths and course angles of the running waves. 


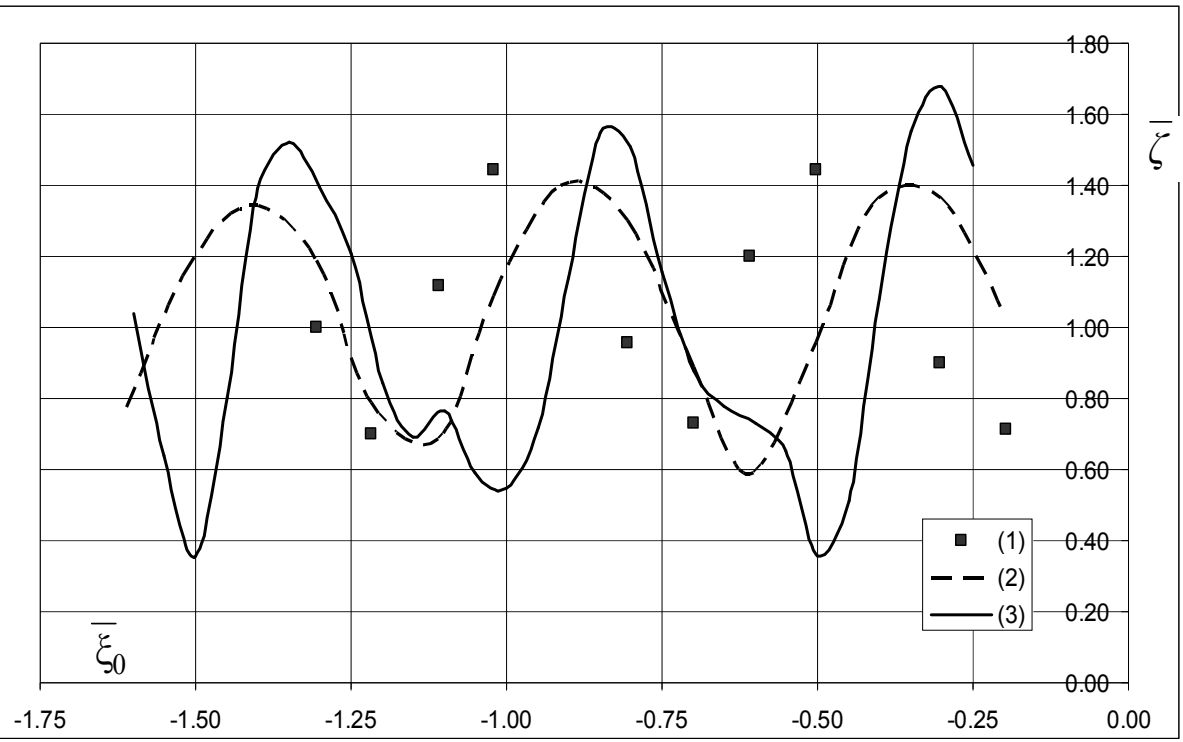

Figure 3. Relative waves' amplitudes along sensors' line at the incoming side $2 \mathrm{~m} / L=0, H / T=1,1, \beta=90^{\circ}$ : 1 -experiment; 2 - linear theory; 3 -nonlinear theory

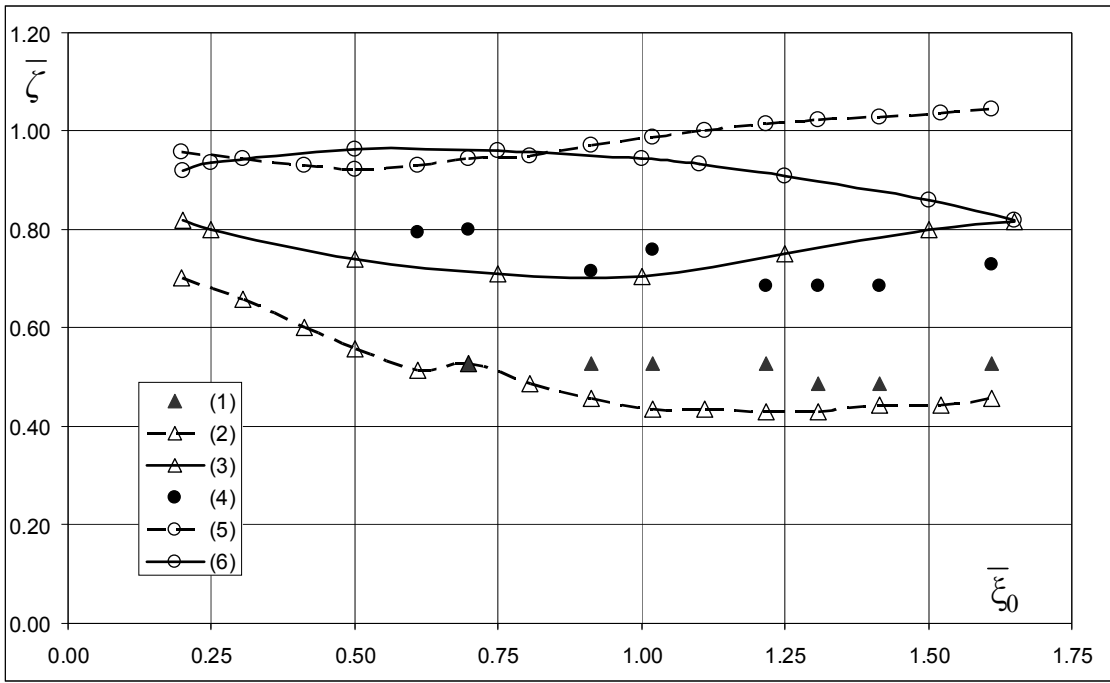

Figure 4. Relative waves' amplitudes along sensors' line at the shadow zone, $H / T=1,1, \beta=90^{\circ}$ at different distances from model's middle to sensor's line

$2 m / L=0: 1$-experiment; 2 - linear theory; 3 -nonlinear theory; $2 m / L=0,5: 4$-experiment; 5 -linear theory; 6 -nonlinear theory 


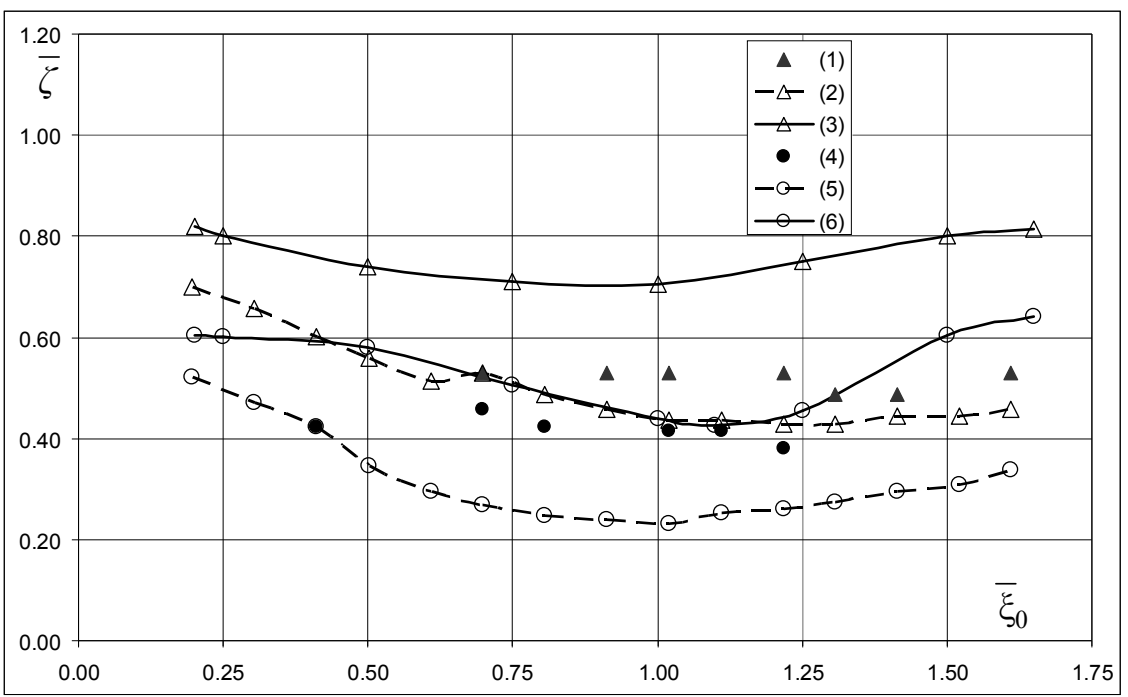

Figure 5. Relative waves' amplitudes along sensors' line at the shadow zone $2 m / L=0, \beta=90^{\circ}$ at different depth:

$H / T=1,1: 1$-experiment; 2 - linear theory; 3 -nonlinear theory; $H / T=1,3: 4$-experiment; 5 - linear theory; 6 -nonlinear theory

During the experiments it has been discovered that significant part of the experimental points for relative wave's length $\lambda / L=0,5$ lay above the computational linear curves. For course angle $90{ }^{\circ}$ it turned out so in the zone of the hydrodynamic shadow, and for angle $135^{\circ}$ at the incoming side. There were no nonlinear computations of waves' characteristics for that moment.

The computational results shown in the paper [21] are wave profiles (wave ordinates at the designated moments of time) around the vessel's hull at the incoming side. For comparison of experimental and theoretical data, linear and nonlinear computations of waves' characteristics at the field of hydrodynamic shadow were carried out. The maximal for the period wave ordinates were defined for the incoming side, i.e. at the zone of the standing wave. Upper envelope curves are plotted for waves' ordinates for passed waves, i.e. at the hydrodynamic shadow zone. For nonlinear computations results are given in the form of $\bar{\varsigma}=2 \varsigma / h$ ( $h$ - height of the running waves).

The number of experimental points used in the given paper is less than in the paper [23] as only part of them corresponds to steepness $h / \lambda=1 / 40$ of running waves from [21]. The number of other varied parameters is reduced for the same reason. Two values of course angles $90^{\circ}$ and $135^{\circ}$ were used, such as two values of relative depth $H / T=1,1 ; 1,3$ and single relative waves' length $\lambda / L=0,5$. 
Differences of characteristics of diffracted and passed waves (wave field at the incoming side and at shadow zone) are visible at comparison of Figures 3 and 4. Changes of distribution of wave amplitudes by vessel's length can be estimated by Figure 4. Influence of water depth on wave field characteristics is visible from comparison of corresponding curves in Figure 5.

Comparison of computational and experimental data allows to reveal the following regularities.

1. Experimental points occupied zone that is located either above linear theory curve and under nonlinear theory curve or under both curves.

2. Waves' amplitudes computed theoretically and measured experimentally differ from each other by about $15-20 \%$ at both the incoming side and at the hydrodynamic shadow zone.

3. The experimental data are close to the theoretical one at the incoming zone.

4. Maxima and minima of standing waves that locate at the incoming zone lay at some distance from the vessel's side. This distance measured experimentally differs from same distance computed by linearly and nonlinearly. In the experiment it was very hard to define this distance more accurate as measurements were made in discrete points where vertical motions of water level were not obligatory of extreme character.

5. At the zone of the hydrodynamic zone, the character of the distribution of experimental waves' amplitudes differs from the computed data by presence and arrangement of extrema.

6. For the course angle $90^{\circ}$ of running waves, alternation of waves' amplitudes and their distribution by vessel's length is more brightly expressed than for angle of $135^{\circ}$ when water depth changes.

7. For the course angle $135^{\circ}$ of running waves the number of the experimental points that corresponds to steepness $h / \lambda=1 / 40$, is not enough. Reduction of wave steepness in experiment has been caused by influence of the wave reflected from walls of towing tank on stability of the resulting wave profile. Therefore it is not possible to draw a conclusion about conformity of experimental and theoretical wave data.

The gained results are of preliminary type and can be used for improvement of experimental methodology for waves around the vessel both for deep water or shallow water.

Conclusions. Analyzing the above mentioned, it is possible to draw the following:

- experiment result data conforms to theoretic one enough satisfactory;

- the nonlinear computations in all cases define the maximal values of wave amplitudes, corresponding experimental values always are less;

- the further investigations should be carried out with more abrupt waves, and also at the increased number of sensor points. 


\section{СПИСОК ЛІТЕРАТУРИ}

1. Лопатухин Л.И. Ветровое волнение: учеб. пособие / Л.И. Лопатухин; СПГУ. СПб.: ВВМ. 2012. 165 c.

2. Manual on oil pollution. Section IV: Combating oil spills // International Maritime Organization. London. 2005. 212 p.

3. Isobe Masahiko. Evolution of basic equations for nearshore wave field/Masahiko Isobe // Proc. Jpn. Acad. 2013. № 89. P. 24-50.

4. Аббасов И.Б. Трехмерное моделирование наката нелинейных поверхностных гравитационных волн на береговые склоны/ И.Б. Аббасов // Ж. вычисл. матем. и матем. физ. 2014. Т. 54. № 5. C. $871-886$.

5. Zhu, Song-Ping. Diffraction of ocean waves around a hollow cylindrical shell structure/ Song-Ping Zhu, L. Mitchell // Wave Motion. 2009. № 46. P. 78-88.

6. Zhu, Song-Ping. Combined diffraction and radiation of ocean waves around an OWC device/ Song-Ping Zhu, L. Mitchell // Journal of Applied Mathematics and Computing. 2011. №. 36. P. 401-416.

7. Wang, C.Z. Second-order wave radiation by multiple cylinders in time domain through the finite element method / C.Z. Wang, S. Mitra, B.C. Khoo // Ocean Systems Engineering. 2011. № 4. V. 1. P. 317-336.

8. Bai, Wei. Simulation of second-order wave interaction with fixed and floating structures in time domain [Text]/ Wei Bai, BinTeng // Ocean Engineering. 2013. V. 74. P. 168177.

9. Aggarwal, Ankit. Irregular Wave Forces on a Large Vertical Circular Cylinder / Ankit Aggarwal, Mayilvahanan Alagan Chella, Arun Kamath, Hans Bihs, Øivind Asgeir Arntsen // Energy Procedia. 2016. V. 94. P. 504-516.

10. Zhong, Z. Modeling fully nonlinear shallow-water waves and their interactions with cylindrical structures / Z. Zhong, K.H. Wang // Computers \& Fluids. 2009. N. 38. P. 1018-1025.

11. Goren, $O$. Second-order wave diffraction by horizontal rectangular barriers / O. Goren, S.M. Calisal // Canadian Journal of Civil Engineering. 2011. № 38. V. 5. P. 546-555.

12. Song, Juhun. Dynamic characteristics between waves and a floating cylindrical body connected to a tension-leg mooring cable placed in a simulated offshore environment / Juhun Song, SooHyun So, Hee-Chang Lim // International Journal of Naval Architecture and Ocean Engineering. 2016. № 8. P. 375-385. 
13. Sulisz, $W$. Reflection and transmission of nonlinear water waves at a semi-submerged dock / W. Sulisz // Arch. Mech. 2013. V. 65. № 3. P. 237-260.

14. Мореходность судов и средств океанотехники. Методы оченки: монография / Под ред. И.К. Бородая // ФГУП «Крыловский государственный научный иентр». СПб., 2013. 256 с.

15. Костров И.С. Гидродинамическая теория продольной качки судна, движущегося на значительном мелководье / И.С. Костров // Вісник ОНМУ. 2009. № 27. С. 49-59.

16. Семёнова В.Ю. О влиянии мелководья на значения присоединенных масс и коэффичиентов демпфирования судна / В.Ю. Семёнова, Тан Хтун Аунг // Морские интеллектуальные технологии. 2011. № 1. С. 10-14.

17. Семенова В.Ю. Определение нелинейных сил второго порядка, возникающих при поперечной качке контура на тихой воде в условиях мелководья / В.Ю. Семенова, Со Чжо Ту // Морские интеллектуальные технологии. 2012. № 2. С. 22-26.

18. Essen, Sanne. Linking Experimental and Numerical Wave Modelling / Sanne van Essen, Jule Scharnke, Tim Bunnik, Bülent Düz, Henry Bandringa, Rink Hallmann, Joop Helder // J. Mar. Sci. Eng. 2020. V. 8. Iss. 198.

19. Egorov, G.V. Features of the CV03 concept of floating transshipment complex with open cargo hold / G.V. Egorov, V.I. Tonyuk, A.G. Egorov, A.V. Demidyuk // Proc. 18th Int. Con. of IMAM. 2019. P. 338-345.

20. Efremova, N. Determining the characteristics of diffracted waves of small amplitude around a vessel in shallow water / N. Efremova, A. Nilva, N. Kotovskaya, M. Dryha // Східно-Свропейський журнал передових технологій. 2017. V. 2(5 (86)). C. 59-67.

21. Efremova, N. Determining the characteristics of diffracted waves of finite amplitude around a vessel in shallow water / N. Efremova, A. Nilva, N. Kotovskaya, M. Dryha // Східно-Свропейський журнал передових технологій. 2019. V. $4(5$ (100)). C. 39-48.

22. Ефремова Н.В. Экспериментальные исследования дифрагированного волнового поля вблизи судна на мелководье / Н.В. Ефремова // Вісник ОДМУ. 1998. № 1. С. 86-89.

23. Ефремова Н.В. Определение параметров качки малого судна при подходе к судну-партнеру на рейдовой стоянке: Дис. ... канд. техн. наук // Н.В.Ефремова; ОГМУ. Одесса, 2001. 173 с. 


\section{REFERENCES}

1. Lopatuhin, L.I. (2012). Vetrovoe volnenie [Wind waves]. SanktPeterburg: VVM, 165 [in Russian].

2. Manual on oil pollution - Section IV: Combating oil spills (2005). International Maritime Organization, 212.

3. Isobe, M. (2013). Evolution of basic equations for nearshore wave field. Proceedings of the Japan Academy, Series B, 89(1), 34-50. doi:https://doi.org/10.2183/pjab.89.34

4. Abbasov, I.B. (2014). Trekhmernoe modelirovanie nakata nelineynyh poverhnostnyh gravitatsionnyh voln na beregovie sklony [Tree-dimensional modelling of uprush of nonlinear surface gravity waves onto shore line]. Zh. vychisl. matem. i matem. fiziki, 54 (5), 871-886 [in Russian].

5. Zhu, S.-P., Mitchell, L. (2009). Diffraction of ocean waves around a hollow cylindrical shell structure. Wave Motion, 46 (1), 78-88. doi: https://doi.org/10.1016/j.wavemoti. 2008.09.001

6. Zhu, S.-P., Mitchell, L. (2010). Combined diffraction and radiation of ocean waves around an OWC device. Journal of Applied Mathematics and Computing, 36 (1-2), 401-416. doi: https://doi. org/10.1007/s12190-010-0410-y

7. Wang, C.Z., Mitra, S., Khoo, B.C. (2011). Second-order wave radiation by multiple cylinders in time domain through the finite element method. Ocean Systems Engineering, 1 (4), 317-336. doi: https://doi.org/10.12989/ose.2011.1.4.317

8. Bai, W., Teng, B. (2013). Simulation of second-order wave interaction with fixed and floating structures in time domain. Ocean Engineering, 74, 168-177. doi: https://doi.org/10.1016/j.oceaneng. 2013.07.014

9. Aggarwal, A., Chella, M. A., Kamath, A., Bihs, H., Arntsen, Ø.A. (2016). Irregular Wave Forces on a Large Vertical Circular Cylinder. Energy Procedia, 94, 504-516. doi: https://doi.org/10.1016/ j.egypro.2016.09.223

10. Zhong, Z., Wang, K.H. (2009). Modeling fully nonlinear shallowwater waves and their interactions with cylindrical structures. Computers \& Fluids, 38 (5), 1018-1025. doi: https://doi.org/ 10.1016/j.compfluid.2008.01.032

11. Goren, O., Calisal, S.M. (2011). Second-order wave diffraction by horizontal rectangular barriers. Canadian Journal of Civil Engineering, 38 (5), 546-555. doi: https://doi.org/10.1139/l11-027 
12. Song, J., So, S.-H., Lim, H.-C. (2016). Dynamic characteristics between waves and a floating cylindrical body connected to a tension-leg mooring cable placed in a simulated offshore environment. International Journal of Naval Architecture and Ocean Engineering, 8 (4), 375-385. doi: https://doi.org/10.1016/j.ijnaoe. 2016.05.003

13. Sulisz, W. (2013). Reflection and transmission of nonlinear water waves at a semi-submerged dock. Archives of Mechanics, 65 (3), 237-260.

14. Boroday, I.K. (Ed.) (2013). Morekhodnost' sudov i sredstv okeanotekhniki. Metody otsenki [Seakeeping of vessels and ocean crafts. Methods of estimation]. Sankt-Peterburg, 256 [in Russian].

15. Kostrov, I.S. (2009). Gidrodinamika prodol'noy kachki sudna, dvizhuschegosya na znachitel'nom melkovod'e [Hydrodynamic of longitudinal motions of the vessel running in significant shallow water]. Visnyk Odeskoho natsionalnoho morskoho universytetu, 27, 49-59 [in Russian].

16. Semenova, V.Yu., Aunh, T.H. (2011). O vliyanii melkovod'ya na znacheniya prisoedinennyh mass $i$ koeffitsientov dempfirovaniya sudna [Concerning shallow water influence on value of added masses and damping coefficients of a vessel]. Morskie intellektual'nie tekhnologii, 1, 10-14 [in Russian].

17. Semenova, V.Yu., Tu S.-H. (2012). Opredelenie nelineynyh sil vtorogo poryadka, voznikayuschih pri poperechnoy kachke kontura na tikhoy vode $v$ usloviyah melkovod'ya [Definition of the nonlinear second order forces arisen at transverse frame contour motions at shallow still water]. Morskie intellektual'nie tekhnologii, 2, 22-26 [in Russian].

18. Essen, S., Scharnke, J., Bunnik, T., Düz, B., Bandringa, H., Hallmann, R., Helder, J. (2020). Linking Experimental and Numerical Wave Modelling. J. Mar. Sci. Eng., 8, 198.

19. Egorov, G.V., Tonyuk, V.I., Demidyuk, A.V. (2019). Features of the CV03 concept of floating transshipment complex with open cargo hold. Proc. 18th Int. Con. of IMAM, 338-345.

20. Efremova, N., Nilva, A., Kotovskaya, N., Dryha, M. (2017). Determining the characteristics of diffracted waves of small amplitude around a vessel in shallow water. Eastern-European Journal of Enterprise Technologies, 2 (5 (86)), 59-67. doi: https://doi.org/ 10.15587/1729-4061.2017.99312

21. Efremova, N., Nilva, A., Kotovskaya, N., Dryha, M. (2019). Determining the characteristics of diffracted waves of finite amplitude around a vessel in shallow water. Eastern-European Journal of Enterprise Technologies, 4 (5 (100)), 39-48. doi: https://doi.org/ 10.15587/1729-4061.2019.173909 
ВІСНИК

ОДЕСЬКОГО НАЦІОНАЛЬНОГО

МОРСЬКОГО УНІВЕРСИТЕТУ

№ 2 (62), 2020
HERALD

OF THE ODESSA NATIONAL

MARITIME UNIVERSITY

№ 2 (62), 2020

22. Efremova, N.V. (1998). Eksperimental'noe issledovanie difragirovannoho volnovoho polya vblizi sudna na melkovod'e [Experimental investigation of diffracted wave field around a vessel in shallow water]. Visnyk Odeskoho derzhavnoho morskoho universytetu, 1, 86-89 [in Russian].

23. Efremova, N.V. (2001). Opredelenie parametrov kachki maloho sudna pri podhode $k$ sudnu-partneru na reydovoy stoyanke [Definition of motions parameters of a small craft that approaches to a partner vessel at the road anchorage]. Dis. ... kand. tekhn. nauk, Odessa, 173 [in Russian].

Стаття надійшла до редакиії 20.04.2020

Посилання на статтю: Ефремова Н.В., Нильва А.Е., Котовская Н.Н., Дрыга М.В. Теоретико-экспериментальные исследования волнового поля вблизи судна на мелководье // Вісник Одеського національного морського університету: Зб. наук. праць, 2020. № 2(62). C. 72-89. DOI 10.47049/2226-18932020-2-72-89.

Article received 20.04.2020

Reference a JournalArtic: Efremova, N., Nilva A., Kotovskaya N., Driga M. Theoretical and experimental investigations of wave field around vessel in shallow water. 2020. 2(62), 72-89 // Herald of the Odessa national maritime university. DOI 10.47049/2226-1893-2020-2-72-89. 